\title{
VÄITLUS
}

\section{EESTI- JA LIIVIMAA TALURAHVA OLUKORRAST ROOTSI AJA LÕPUS}

\author{
SisSEJUHATUS
}

Käesoleva aasta 2. mail toimus Akadeemilise Ajalooseltsi korraldusel seminar teemal "Pärisorjus või vabadus: muutused talurahva olukorras Rootsi aja lõpus". Seminar oli ajendatud Eesti ajalooteaduses viimasel peaaegu paarikümnel aastal toimunud diskussioonist Eesti- ja Liivimaa (kroonu) talupoegade reduktsioonijärgse seisundi üle. Diskussioon sai alguse Stockholmi ülikooli emeriitprofessori Aleksander Loidi 29. aprillil 1996. aastal Tartu ülikooli ajaloo osakonnas peetud ettekandest "Pärisorjuse kaotamisest Eestis Rootsi ajal", milles ta esitas senisele ajalookirjutusele (nt Juhan Vasar) vastanduva seisukoha, et Rootsi kuningas Karl XI mitte ainult ei kavatsenud Läänemere provintside talurahva olukorda parandada, vaid ka tegelikult kaotas reduktsiooniga riigistatud mõisates pärisorjuse - Liivimaal 1681. aastal ja Eestimaal 1687. aastal. ${ }^{1}$ Mitte kõik toonases seminaris osalenud ajaloolased ei olnud Loidiga ühte meelt. Näiteks jäi Elina Öpik veendumusele, et kroonutalupoegade seisund reduktsiooniga ei muutunud ja talupoegade pärisorjusest vabastamisest ei ole võimalik rääkida. Loidi seisukoha suhtes kriitilisi kirjutisi ilmus järgnevatel aastatel veelgi. ${ }^{2}$ Kuid teda on ka toetatud; kõige jõulisemalt on seda teinud Kalle Kroon. ${ }^{3}$ Samuti

\footnotetext{
Akadeemilise Ajalooseltsi seminar "Pärisorjus või vabadus: muutused talurahva olukorras Rootsi aja lõpus" (2. mail 2013) sai võimalikuks Eesti Teadusagentuuri grandi PUT119 toetusel.

1 Vt Aleksander Loidi seisukohti: Aleksander Loit, "Pärisorjuse kaotamine Eestis Rootsi ajal”, Kleio. Ajaloo ajakiri, 1 (15) (1996), 3-18; ülevaade seminarist: Lea Leppik, "Seminar pärisorjuse kaotamisest Rootsi ajal", Kleio. Ajaloo ajakiri, 3 (17) (1996), 61-66. 2 Nt Mati Laur, Katrin Kello, "Rootsi aja pärand 18. sajandi Liivimaa agraarsuhetes", Muinasaja loojangust omariikluse läveni: pühendusteos Sulev Vahtre 75. sünnipäevaks, koost Andres Andresen (Tartu: Kleio, 2001), 251-273.

3 Kalle Kroon, Kolme lõvi ja greifi all Põhjasõjas: eestlased ja lätlased Rootsi armees, nähtuna sotsiaal-majanduslike muutuste taustal 17. sajandi lõpul-18. sajandi alguses
} 
on Loidi arusaam kroonutalupoegade pärisorjusest vabastamisest levinud kodumaistes kooliõpikutes ${ }^{4}$ ja isegi rahvusvahelistes teadusväljaannetes. ${ }^{5}$ Ka 2013. aasta sügisel ilmuva "Eesti ajaloo" kolmanda, Eesti 16.-17. sajandi ajalugu käsitleva köite üheks teemaks on talurahva olukord, sh pärisorjuse ja (kroonu)talupoegade reduktsioonijärgse seisundi küsimus. Vastava peatüki autor on Marten Seppel, kes aga leiab samamoodi kui Öpik, et kroonutalupoegade seisundi muutus polnud piisav, et rääkida pärisorjuse kaotamisest või talurahva vabastamisest, ehkki talupoegade kaitse suurenes tänu fikseeritud normidele jms. Selle Eesti ajalooteaduse seisukohast olulise teema taas põhjalikumaks läbiarutamiseks, erinevate seisukohtade argumenteeritult esitamiseks, väidete analüüsimiseks ja võimalusel arusaamade lähendamiseks uus seminar aset leidiski. Seminaril esinesid neli selle teemaga tegelevat ajaloolast: Aleksander Loidi kõrval noorema põlvkonna esindajad Kalle Kroon, Aivar Põldvee ja Marten Seppel. Pärast seisukohtade esitamist toimunud diskussioon keskendus kitsamatele teemadele, nagu eesti ja läti talupoegade võimalus osaleda tsiviil- ja sõjaväeteenistuses, kroonu- ja eratalupoegade seisundi võrdlus jms, kuid peateema kõrval vaadeldi Karl XI absolutistlikus vaimus läbi viidud reforme üldisemalt, näiteks kuidas reformid mõjutasid Eesti- ja Liivimaa sotsiaalmajanduslikke suhteid, millised muutused leidsid aset aadli läänisuhetes kuningavõimuga, aga ka talurahva kultuuri ja haridusoludes jne. Alljärgnevalt avaldatavad ettekannete teesid teevad vahekokkuvõtte esinejate seisukohtadest - diskussioon jätkub.

ENN KÜNG

(Tallinn: Argo, 2007). Viimati: Kalle Kroon, "Eestlaste vabadusest ja väest Rootsi aja lõpul", Horisont, 2 (2013), 38-46.

4 Andres Adamson, Sulev Valdmaa, Eesti ajalugu gümnaasiumile (Tallinn: Koolibri, 1999), 78; Andres Adamson, Toomas Karjahärm, Eesti ajalugu gümnaasiumile (Tallinn: Argo, 2004), 101.

5 Hiljuti ilmunud töödest vt nt Raimo Raagi artiklit kogumikus: Från Nyens skans till Nya Sverige: språken i det Svenska Riket under 160o-talet, red. Bo Andersson \& Raimo Raag, Kungl. Vitterhets historie och antikvitets akademien; Konferenser, 78 (Stockholm: Kungl. Vitterhets historie och antikvitets akademien, 2012). 


\section{FeodaAlKorra lagunemine Eestis}

Kui eestlaste asualad 16. ja 17. sajandil Rootsi võimu alla liideti, valitses siin juba väljakujunenud feodaalkord aadlikest mõisnike ja neile alluvate talupoegadega. See olukord süvenes veelgi Rootsi aja algul, kui algselt ulatuslikud kroonu maavaldused peaaegu täielikult aadlile läänistati. Tagajärjeks oli mõisate arvu hüppeline kasv, mõisapõldude ulatuslik laienemine ja sellele vastavalt talupoegade koormiste märgatav suurenemine - seega leidis aset mõisamajanduse jõuline ekspansioon.

Kroonumaade peaaegu täielik läänistamine ei tähendanud mitte ainult riigi sissetulekute olulist kahanemist, vaid sellega kaasnes tähtsate riigiõiguslike ja halduslike funktsioonide üleandmine aadlikest läänisaajatele, kelle mõisad said nüüd avalik-õiguslike institutsioonide staatuse. Läänistatud aladel ei saanud riigivõim end enam täielikult maksma panna. Rootsi aja lõpus võime aga täheldada mitmeid muutusi senistes arengutes. Pööre tuli reduktsiooniga, kui kõik Rootsi-aegsed läänistused taasriigistati ja suurem osa haritavast maast tuli kroonu valdusesse. Lisaks sellele, et riigi sissetulekud Eesti- ja Liivimaalt suurenesid mitmekordselt, tõi reduktsioon endaga kaasa mitmed olulised muutused kehtivas ühiskonnakorralduses. Need muutused ei olnud mitte ühiskonna spontaanse arengu tagajärg, vaid absolutistliku Rootsi kuningavõimu sihiteadliku poliitika tulemus. Tähtsaimateks selle poliitika alussammasteks olid läänikorra likvideerimine ja pärisorjuse kaotamine. On märkimisväärne, et nii tähtsat ühiskondlikku nähtust nagu läänikorra likvideerimist Rootsi ajal ei ole teaduslikus kirjanduses problematiseeritud ja see on vaevalt tähelepanu äratanud.

Läänikord oli feodaalühiskonna alustala: ld feudum - lään, feodalism. Läänis olid ühendatud põhilised legaalsed, majanduslikud ja sotsiaalsed suhted feodaalkorra peategelaste - läänihärra, läänisaaja ehk vasalli ja alluvate talupoegade - vahel. Neid suhteid reguleerisid lääniõigus ja aadli privileegid, mis kehtisid üldiselt, ning kollektiivsed ja individuaalsed läänikirjad. Feodaalkorrale iseloomulik oli läänihärra ja vasalli vaheline truudussuhe.

Kohe pärast redutseeritud mõisate ülevõtmist vajas ühe tähtsaima küsimusena lahendamist see, kuidas kõige otstarbekamalt majandada kroonu uut suurt maavaldust. Olukorda arutati põhjalikult nii Stockholmis kui ka Eesti- ja Liivimaa kohalikes instantsides. Mõeldavad olid viis alternatiivi: 1) anda mõisad välja pooletera tingimustel; 2) varuda maad kavandatavale uuele sõjaväeorganisatsioonile (indelningsverket);3) mõisate partselleerimine ja asustamine talupoegadega; 4) mõisate väljarentimine ning 5) valduste kroonupoolne haldamine mõisavalitsejate abil. Nagu teada, valiti majanduslikel ja poliitilistel põhjustel mõisate rendile andmise tee. 
Arutelude käigus rõhutati korduvalt, et redutseeritud mõisate uuesti läänistamine, mida eriti baltisaksa rüütelkonnad ihaldasid, oli absoluutselt välistatud. Seega kadus mitmesaja-aastane maavaldusvorm täielikult Rootsi keskvalitsuse praktikast ja ühtlasi Eesti- ja Liivimaalt.

Kroonumõisates asendati läänikord kasutusrendile andmisega. Pealiskaudselt vaadates võib nende kahe maavaldusvormi vahel leida mõningaid sarnasusi. Enamik rentnikke olid samad isikud, kes olid mõisaid kui läänistusi juba varemgi valitsenud. Suuresti muutumatuks jäi mõisate vahekord neile alluvate maksu- ja teokohustuslike talupoegadega. Lähemalt vaatlusel selgub aga, et läänistamise ja rendile andmise vahel ei olnud ainult suured erinevused, vaid et need kaks maavaldusvormi olid nähtused, mis kuulusid hoopis erinevatesse majanduslikesse ja sotsiaalsetesse ühiskonnakordadesse. Sellest annab tunnistust juba rida formaalsusi. Lääni juriidiline alus oli läänihärra poolt antud ja lääniõigusele ning aadliprivileegidele rajanev isiklik läänistuskiri, seega armuosutus feodaalse püramiidi tipust. Rent aga rajanes vabal kokkuleppel kahe põhimõtteliselt võrdse osalise kroonu ja rentniku - vahel. Rendile võtmine toimus rentniku soovil ja tal oli õigus rendilepingust lahti öelda; sama õigus oli ka kroonul. Läänistamise puhul otsustas läänihärra ühepoolselt, milliste tingimustega läänistamine toimus - paremate tingimuste puhul anti läänistused "igaveseks ajaks", samas kui kroonu andis oma maad rendile "valdusõiguse alusel".

Kahe maavaldusvormi olemuslik erinevus paistis täiel määral silma siiski läänikorra ja rendikorra majanduslike ja sotsiaalsete tingimuste juures, seda eriti maa-aadli olukorda puutuvalt. Kui riigi sissetulekud Eesti- ja Liivimaalt enne reduktsiooni olid üpris kasinad, siis moodustasid redutseeritud mõisate sissetulekud siit ligemale ühe kolmandiku reduktsiooni sissetulekutest kogu Rootsis. Vastavalt sellele vähenesid rentnike tulud. Üleminek läänikorralt rendisüsteemile tähendas seega ulatuslikku ressursside ümberjaotust aadlilt kroonule. Kuna pool rendisummast tuli tasuda sularahas, siis pidanuks üleminek rendikorrale pikemas perspektiivis tõenäoliselt soodustama põllumajanduse arengut feodaalsest, autarkilisest naturaalmajandusest enam turule orienteeritud rahamajandusele. Seda mõeldavat arengut võib ka iseloomustada kui üleminekut põhimikuhärruselt (Grundherrschaft) mõisamajandusele (Gutswirtschaft).

Mitte väiksema tähendusega oli murrang sotsiaalsetes vahekordades. Paralleelselt aadli halvenenud majandusliku olukorraga nõrgenes ka tema poliitiline võim ja sotsiaalne staatus - nii suhetes ainuvalitsusliku kuningavõimu kui ka alluvate talupoegadega. Aadlikest mõisahärrade isiklik, truudusvandega kinnitatud vahekord kuninga kui läänihärraga oli asendunud 
rentniku ja kroonu vahelise isikupäratu, ärilise suhtega. Mitmed tähtsad ühiskondlikud funktsioonid, nagu näiteks maksude sissenõudmine ja õigusemõistmine, olid reduktsiooniga viidud endiste mõisahärrade käest kohaliku riikliku halduse alla. Endistest feodaalsetest mõisahärradest olid saanud alluvate talupoegade maksu- ja teokohustusest elatuvad rantjeed, vabade rendilepingute alusel tegutsevad ettevõtjad riigi maavaldusel - seega üks nähtus, mis kuulub pigem kapitalistlike tootmistingimuste valdkonda.

Sellega ei olnud aga vana feodaalaadli degradeerimine veel lõppenud. Riigimõisate rentnikud ei võinud enam kuuluda kohalikesse rüütelkondadesse ning rüütelkondadel ei olnud luba esindada rentnikke riigivõimu ees. Rentnikel ei tohtinud olla ka oma organisatsiooni, mis oleks kaitsnud nende huve. Oma soove ja kaebusi võisid rentnikud esitada ainult ükshaaval kubermangu majandusametnikele. Nad ei tohtinud end enam ka tituleerida oma endiste läänimõisate nimedega, kus nad pealegi olid kaotanud patronaadiõiguse kiriku üle. Samuti kaotasid rentnikud mitmed feodaalsed prerogatiivid, nagu näiteks maritagium'i (talupoegade kohustus maksta mõisahärrale teatud rahasumma, kui nende tütred abiellusid väljapoole mõisa piire).

Balti provintside aadlikorporatsioonid - rüütelkonnad - said tunda kuningliku ainuvalitsuse valju kätt. Maapäevadelt võeti initsiatiiv algatada aadlile oluliste küsimuste käsitlemist ja Liivimaa maanõunike kolleegium likvideeriti hoopis. 1690. aastatel Eesti- ja Liivimaal maksma pandud uus ametiastmestik (rangordning, rangide kord) sundis aadlikke astuma riigiteenistusse, peamiselt ohvitseridena. Ametiaste määras isiku ühiskondliku positsiooni kuni tema abikaasa kohani kirikupingis. Seades ametiastme enne päritolu, karmistas ainuvalitsuslik kuningas kontrolli aadli üle veelgi enam. Üldiselt võib väita, et senine feodaalne, seisuslikul korral baseerunud aadliomavalitsus asendus nüüd riikliku bürokraatiaga. Ka reduktsioonist vabastatud vanade aadlimõisate osas korraldati ulatuslik privileegide kontroll, kusjuures võidi avastada mõisaid, mis olid aegade jooksul läinud väljapoole privileegides stipuleeritud pärijate ringi (viies sugulusaste). Sellistel juhtudel võisid ka need mõisad kuuluda redutseerimisele. Samuti degradeeris vana indigenaataadli sotsiaalset positsiooni ulatuslik mitteaadlikest ohvitseride ja madalamate ametnike aadeldamine.

Läänikorra likvideerimine mõjutas otseselt talupoegade olukorda, mis avaldus kõige otsustavamalt nende vabastamises pärisorjusest. Seda küsimust arutati nii riigi keskvõimude kui ka provintsivalitsuste poolt küllaltki põhjalikult, seevastu ei käsitletud üldse pärisorjuse üldist olemust. Rootsis ei olnud pärisorjust, mistõttu probleem Baltimaade pärisorjusest 
tuli lahendada pragmaatiliselt - pärisorjus oli just see konkreetne olukord, milles siinne talurahvas elas. Oma otsused pärisorjuse kaotamise kohta sõnastas Karl XI nii, et talupojad Eesti- ja Liivimaa kroonumõisates ei olnud enam aadli pärisorjad (livegna), vaid kuninga alamad ja neid tuli edaspidi kohelda nagu kõiki teisi talupoegi Rootsi riigis.

Pärisorjuse kaotamise küsimuses esineb vastandlikke arvamusi. Ühed leivad, et Karl XI otsused vabastada Eesti- ja Liivimaa kroonumõisate talupojad pärisorjusest on vaieldamatult dokumenteeritud ja neid hakati ka ellu viima. Teised aga väidavad, et pärisorjus jäi püsima, viidates rea üksikjuhtumite varal pärisorjuse teatud elementide säilimisele. Kui aga eitada pärisorjuse kaotamist, siis järeldub sellest loogiliselt, et eitatakse Karl XI otsuste olemasolu üldse või vähemalt nende legitiimsust. Antud probleemi käsitlemisel aga ei ole kuidagi võimalik ignoreerida Karl XI sellekohaseid otsuseid või kummutada neid tagantjärele tarkusega sellest, mis juhtus järgneva Vene valitsuse ajal.

Karl XI põhimõtteline otsus tuli ellu viia, esmajoones jälgides 169o. aastate ettekirjutusi majandusasehaldurite instruktsioonides ja ökonoomikareglemendis. Nüüd seati sisse uued vakuraamatud, kus talupoegade kohustused mõisa vastu olid täpselt määratletud. Samas kehtestati ka ranged eeskirjad mõisarentnikele, et need ei vaevaks talupoegi ülemääraste koormiste nõudmisega. Vastasel juhul ootas rentnikku rahaline karistus või isegi rendilepingust lahti ütlemine. Samuti garanteeriti talupoegadele õigus esitada kaebusi rentnike vastu. Mõisakohustuste normeerimist on nähtud kui kindlat märki sellest, et talupojad ei olnud enam pärisorjad.

Koos talupoegade kohustuste normeerimisega rakendati preventiivseid meetmeid, et kindlaksmääratud norme järgitaks. Pikemas perspektiivis oleks kohustuste normeerimine tähendanud seda, et talupojad oleks saanud endale jätta hoopis suurema osa oma toodangu ülejägigist kui varem. Ühiskonnateoreetilise terminiga võiks seda protsessi kirjeldada kui lisaprodukti ümberjaotamist.

Et pärisorjuse kaotamine ei andnud kohe kiireid tulemusi, ei tohiks tulla üllatusena. Ka heade eelduste puhul oleks sellise reformi läbiviimine nõudnud oma aja. Aga eeldused ei olnud head. 1690. aastatel maad tabanud ikaldused, näljahäda ja katk pöörasid riigivõimu peatähelepanu ja -tegevuse neile õnnetustele ning varsti pärast seda puhkenud Põhjasõda tõi Eesti- ja Liivimaale Vene vägede rüüstamised. Pealegi, kus ja millal maailma ajaloos kohtame reformipoliitikat, mis murdnuks mitmesaja-aastast kehtivat ühiskonnakorda üleöö? 
Ometi algas nüüd Karl XI otsuste elluviimine, mis tõi endaga kaasa mitmeid muutusi talupoegade olukorras, mida saab otseselt seostada pärisorjuse kaotamisega. Pärisoriste eesti talupoegade osalemine avalikus elus oli olnud minimaalne. Pärast vabastamist võime märgata nende aktiivsuse tõusu mitmes ühiskonna sektoris. Nii näiteks osalesid nad redutseeritud mõisate tootmisvõimsuse kindlaks määramisel, mille alusel fikseeriti rendisummad. Siin on väärt täheldada, et reduktsioonikomissarid usaldasid rohkem neid andmeid, mis nad olid saanud talupoegadelt, kui neid, mida esitasid mõisahärrad ja -valitsejad. Samuti pandi paika talupoegade roll kohalikus kohtumõistmises ja 169o. aastatel kavandatud uues kohtukorralduses olid neile isegi ettenähtud kaasistujate kohad maakohtutes.

Hästi on teada eesti talupoegade massiline nekrutiksvõtmine ja värbamine Rootsi sõjaväkke Põhjasõja aastail, mida tuleks näha selle taustal, et talupoegade relvateenistus ja relvakandmine üldse ei olnud ühendatav pärisorjuse institutsiooniga. Vähem on aga teada, et Rootsi võimudel olid kindlad plaanid Eesti- ja Liivimaal sisse viia maapalgalise sõjaväe organisatsioon (indelningsverket), mis oleks avanud suurele hulgale eesti talupoegadele võimaluse lahkuda mõisaorjusest ja minna torpariks (sõdur-talupojaks) Rootsi sõjaväkke. Lisaks oli võimudel kavatsus rajada redutseeritud mõisatesse manufaktuurid, kus pärisorjusest vabastatud talupojad oleksid saanud palgatöölisteks.

Lõpuks võiks veel mainida talupoegade suurenenud osalust kohalikus kiriku- ja koguduseelus. Vastasutatud rahvakoolide rajamine ja käigushoidmine ei oleks olnud võimalik ilma maarahva aktiivse toeta. Piibli tõlkimisel tekkinud keeletülides kasutati talupoegade teadmisi nende vaidlusosaliste poolt, kes eelistasid tõlkes rohkem rahvalikku keelt. Siintoodud valikulised näited talupoegade olukorrast pärast pärisorjuse kaotamist viitavad kõik samas suunas - suurema vabaduse ja ühiskondliku aktiivsuse poole.

Pärisorjuse kaotamine toimus peamiselt poliitilistel motiividel. Rootsi oli vaene Euroopa suurvõim, millel nappis inimressursse. Läänemere provintside rahvastikust oli 90-95 protsenti mõisaorjad, kellest ei olnud riigile mingit kasu. Nende lahtirakendamisega mõisa sundusest vabanes suur tööjõutagavara just selles riigi osas, kus vajadus selle järele oli kõige suurem. Samaaegselt oleks vabast talupojaseisusest saadud balansseeriv vastukaal ja riigi keskvõimu liitlane alati opositsioonilise aadli vastu - nii nagu Rootsis. Just arengut Rootsis on sealne rahvusvaheliselt tuntud ajaloolane Eli Heckscher kirjeldanud järgnevalt: "Reduktsioon ja selle järelreformid päästsid Rootsi talupojad aadlikest suurmaavaldajate ekspluateerimisest. Reduktsioon hävitas feodaalsete suhete võõrad jäljed ja see, 
mille reduktsioon oli kukutanud, ei tulnud enam iial tagasi." See hinnang võinuks kehtida ka Eesti- ja Liivimaa kohta. Pärisorjuse kaotamine Läänemere provintsides oli üks osa Rootsi provintsiaalpoliitika peamisest sihist tugevdada integratsiooni- ja unifitseerimispoliitika läbi Rootsi riigi ühtsust (unus rex, una lex et grex unus - "üks kuningas, üks seadus, üks rahvas").

Läänikorra likvideerimise ja pärisorjuse kaotamise asjaolud Rootsi aja lõpul vajavad veel tublit empiirilist uurimistööd. Edasised uuringud peaksid esmajoones keskenduma talupoegade vabastamise eeldustele, ulatusele ja tempole; samaaegselt ei tuleks neid nähtusi vaadelda mitte isoleeritult, vaid tihedas seoses teiste feodaalühiskonna kriisi ilmingutega. Selline süsteem-analüütiline suund võimaldaks saavutada paremat arusaamist Eestis valitsenud feodaalühiskonna kui terviku arengust, selle ajendeist ja tähendusest. Üksikasjalikumad uuringud ja võrdlused pärisorjuse olemusest Läänemere provintsides ja kontinentaalses Euroopas annavad väärtuslikku lisa meie teadmistele feodaalühiskonnast, aga neil ei ole mingit tähendust küsimusele pärisorjuse kaotamisest Rootsi-aegses Eestis. Selle probleemi lahendas Karl XI vastavasisulise deklaratsiooniga, mille ta kuulutas välja absolutistliku monarhi ainuisikulise juhtimise positsioonilt.

Läänikorra likvideerimine ja pärisorjuse kaotamine olid kõige tähtsamad neist sotsiaalsetest muutustest, mis vapustasid Eestis kehtivat feodaalset ühiskonnakorda Rootsi aja lõpul. Pärast reduktsiooni sai kroonumõisate väljarentimine praktiliselt ainsaks valdusvormiks. Läänikord oli olnud absoluutseks eelduseks pärisorjusele, selle tekkele, arengule ja kadumisele. Seal, kus likvideeriti läänikord, kadus ka pärisorjus. Seal, kus läänikord kestis, näiteks reduktsioonist vabastatud aadlimõisates, püsis ka pärisorjus.

Aleksander Loit

\section{RIIGITALUPOEGADE VABA AMETIVALIKU VÕIMALUSTEST}

Rootsis pärisorjus puudus. Talupojad olid liikumises vabad, nad said valida ameti ja võisid rentida riigilt kasutamiseks maad. Alustades ning läbi viies mõisate riigistamist Eesti- ja Liivimaal, andis Rootsi kuningas Karl XI välja järgmised korraldused: 1681. aasta kevadel tuli Liivimaa reduktsioonikomisjoni esimehel Robert Lichtonil aadli nõusolekust sõltumata anda 
korraldus talupoegade pärisorjuse kaotamiseks ja "vabaduse sisse juhatamiseks" riigimõisates, kaasa arvatud nendes mõisates, mis reduktsiooniga riigi kätte langesid ning et talupoegi edaspidi "ei koheldaks teisiti kui Rootsi riigi talupoegi". ${ }^{6}$ Karl XI kirjaga Eestimaa reduktsioonikomisjonile 31. juulist 1687 tuli riigistatud valduste talupojad jätta küll mõisatesse paigale, kuid neile tuli teatada, et nad on kuninga alamad, lisades, et talupoegade pojad võivad vabatahtlikult asuda kas armeesse või tegeleda "raamatulike kunstidega" ega tohi neid keegi takistada ega tõkestada seni, kuni nad oma teenistust usinuse ja ustavusega peavad. ${ }^{7}$ Liivimaal alustati mõisate tegelikku ülevõtmist riigile 1681. ja Eestimaal 1686. aastal (Eestimaal alustas komisjon tegelikult tööd detsembris 1685$){ }^{8}$ Seni on kuninglikud korraldused Liivimaa osas suurel määral läbi töötamata, kuid nende analoogsus Eestimaale antud korraldustega on empiirilise materjali põhjal tuvastatav. Oma üldseisukoha, et riigimõisate talupoegade poegadel võimaldati ameti valikul reglementeeritult ilmutada vaba tahet, olen avaldanud 2007. aastal. ${ }^{9}$ Alljärgnevalt esitan laiendatud seisukohad eesti (ja läti) talurahva kui riigialamate ametivaliku vabaduse küsimuses Rootsi aja lõpul.

TAlupoegade vabadus astuda ARMEESSE. Rääkides talupoegade sõjaväeteenistusest, tuleb silmas pidada vägede komplekteerimise erinevaid viise. Maakaitsekohustusel tuginevad ebaregulaarsed väeosad loodi talupoegadest siis, kui puhkes sõda. Pärast hädaohu lakkamist siirdusid talupojad oma elukohta tagasi. Regulaarväed moodustati 17. sajandi lópul vabatahtlikkuse alusel värbamise teel ning teenistus regulaarvägedes oli põhimõtteliselt alaline. Vägivaldselt võis värbamispatendi alusel värvata ainult vabadikke ja muud "lahtist" rahvast, ${ }^{10}$ mitte teisi elanikkonna kihte, sealhulgas ka mitte adratalupoegi. ${ }^{11}$ Väeosadele määrati värbamispiirkonnad ja meeste kogumispunktid ning värbajad (paar sõdurit ohvitseri saatel) käisid trummi lüües maal ja linnades ringi ning pakkusid teenistust kuninglikus armees. Värbamise vastuvõtmise vabatahtlikkus on talupoegade vaba tahte avaldumise uurimisel oluline. Vastuse küsimusele, kas pärustalupoja vabatahtlik armeesse minek oli Eesti- ja Liivimaa kohalikele õigusnormidele vastav, saame Riia garnisonis paiknenud ooberst

6 Loit, "Pärisorjuse kaotamine Eestis Rootsi ajal", 7-8.

7 Kroon, Kolme lõvi ja greifi all, 321-322.

8 Loit, "Pärisorjuse kaotamine Eestis Rootsi ajal", 8-9.

9 Kroon, Kolme lõvi ja greifi all, 71.

10 Ibid., 6o.

11 Rootsi maaseaduse kuningaosa: "Das Schwedische Land-und Stadt-Recht” (Riga: Noller, 1709), cap. II, paragr. II (f): "wenn aber einige Werbungen fürzunehmen sind, so müssen selbige ohne Zwang, List und Gewalt geschehen [...]." 
Johan von Campenhauseni rügemendi värbajate juhtumi põhjal. Kuningas Karl XI 1680. aasta patendiga lubati Campenhausenil täiendada oma väeosa 8oo-meheliseks värbamise teel "kõikjal Eesti-, Liivi- ja Ingerimaal, kus ta tahab ja kus on võimalik mehi muretseda". ${ }^{12}$ Kirjas kuningale 4. juulist 1681 kaebas Eestimaa rüütelkond, et Campenhauseni värbajad meelitavad ära nende pärustalupoegi, seades sellega ohtu aadli privileegid, sest talupojad tahtvat nüüd härrade juurest ära minna. ${ }^{13}$

Eestimaa aadli korporatiivsest protestist nähtub, et pärustalupoegade vaba tahte alusel regulaarvägedesse astumine ei olnud kooskõlas kehtivate baltisaksa aadli õigusnormide ja privileegidega, mille kohaselt sunnismaisel talupojal puudus õigus kohalt lahkuda. Campenhauseni värbajad pidid olema leidnud mehi adratalupoegade kui arvukaima talurahvakihi ning mõisamajanduslikult kandva jõu hulgast, sest vabadike sõduriks võtmisega on aadelkond siis ja ka edaspidi nõustunud. Veelgi enam, kui 1701. aastal algas Eesti- ja Liivimaal adratalupoegade sunduslik nekrutiks võtmine ja varustamine, pidas rüütelkond seda meeletuks sammuks, soovitades oma järjekordses protestikirjas kuningale lasta adratalupoegade asemel väkke võtta üksnes vabadikke. ${ }^{14}$ Kui Vene võimu perioodil 1797. aastal hakati uuesti nekruteid võtma, andsid mõisnikud oma maadelt mitte adratalupoegi, vaid vabadikke ja muud "lahtist" rahvast, et mõisamajandus ei saaks oluliselt kahjustatud..$^{15}$ Aadli lootus oma privileegide kaitsmisele Rootsi aja lõpul oli naiivne, sest mõisate riigistamisega kaasnes hoopis privileegide ning rüütli- ja maaõiguse seisundi oluline taandamine Rootsi õiguse ja keskvõimu seaduste ees. ${ }^{16}$

Kuigi seni ei ole leitud Liivimaa kindralkubermangu kohta käivat dokumenti, mis reguleerinuks riigimõisate talupoegade vaba õigust astuda armeesse, on olukord siiski rekonstrueeritav mitme dokumendi alusel. Kirjas kuningas Karl XII-le 29. juulist 1701 teatas Liivimaa kindralkuberner Erik Dahlbergh, et Karl XI ajal oli Riia garnisonirügementidesse värvatud "suurel hulgal läti talupoegi", kes aga kelmuse ehk rehepapluse (bedrägligheet) tõttu olid enamuses vallandatud, "nii et vaevalt veel mõni sellest

12 Margus Laidre, Üks hä tru ja öige sullane: elust Rootsi sõjaväes Eesti- ja Liivimaal 1654-1700 (Tartu: Eesti Ajalooarhiiv, 1999), 185.

13 Laidre, Üks hä tru ja öige sullane, 190.

14 Heldur Palli, Kui Raudpea läks: pildikesi Põhjasõja ajast (Tallinn: Eesti Raamat, 1967), 67; Heldur Palli, Mezhdu dvumya boyami za Narvu: Ėstoniya v pervȳe godȳ Severnő̆ vǒ̀ny 1701-1704 (Tallin: Akademiya nauk Ėstonskoĭ SSR, 1966), 74.

15 Ajalooarhiiv [edaspidi EAA], f. 178, n. 1, s. 3779; Rein Helme, 1812. aasta Eestis ja Lätis (Tallinn: Olion, 1990), 14.

16 Kroon, Kolme lõvi ja greifi all, 70. 
rahvusest teenimas on". ${ }^{17}$ On küsitav, kas "suurel hulgal" oli võimalik vabadikke värvata? Usutavam on, et värbamine toimus ka adratalupoegade seas. Teade liivimaiste talupoegade sobimatusest armeesse jõudis ka Karl XI-ni, kes 16. jaanuaril 1685 väljastas käsu edaspidi "mittesaksa talurahvast" Liivimaal mitte värvata. ${ }^{18}$ Järelikult pidi liivimaiste talupoegade värbamine olema toimunud enne 1685 . aastat, eeldatavasti aastail 1681-85, mil Liivimaal oli läbi viidud mõisate riigistamine. Tagasilöök talupoegade armeesse astumisel Liivimaal ei heidutanud kuningat pakkumast armeesse astumise võimalust kaks aastat hiljem, 1687. aastal Eestimaa riigimõisate talupoegadele. ${ }^{19}$ On alust arvata, et analoogne korraldus väljastati ka Liivimaa kindralkubermangus ning sel juhul pidi see toimuma enne 1685. aasta keeldu. Põhjasõja ajal oli eestlaste värbamine Rootsi armeesse suhteliselt ulatuslik. Otto Liivi andmeil olid neist vähemalt 40 isikut tõusnud ka ohvitseriks, tuntuimad neist olid Virumaalt pärit ooberstleitnant Thomas Jörist ja tema vend leitnant Johan Jörist. ${ }^{20}$

TAlupoegade VAbadus töötada tSivillametis. Kirjas Eestimaa reduktsioonikomisjonile 31. juulist 1687 andis Karl XI talupoegade poegadele õiguse asuda tegelema ka "raamatulike kunstidega", st asuda näiteks köstri või kooliõpetaja ametisse. ${ }^{21}$ Esmaseks kriteeriumiks sellisesse ametisse asumisel oli hariduse omandamine, mida võimaldas talurahvakool..$^{22} \mathrm{Nagu}$ talupoegade armeesse astumisel, nii tuleb ka haridust nõudva ameti puhul eeldada, et analoogne korraldus oli antud ka Liivimaale. Rahvakoolide võrk pidi hõlmama igat kihelkonda. ${ }^{23}$ Aastail 1684-86 Tartu lähedal Piiskopimõisas tegutsenud Forseliuse seminar, kus õpetati eesti talulapsi koolmeistriteks, andis kokku vähemalt 160 kasvandikku. ${ }^{24}$ Aivar Põldvee näitab, et 1686. aastal olid koolilaste õpetajateks Eestimaa kindralkubermangust Ristilt pärit abikooliõpetajad Uustalu Bengt (Ousthal Bengt) ja Jõesuu

17 Riksarkivet [edaspidi RA], Livonica II, 327, E. Dahlberg 29. juulil 1701. a kuningale.

18 Laidre, Üks hä tru ja öige sullane, 190.

19 Kroon, Kolme lõvi ja greifi all, 321-324.

20 Otto Liiv, "Eesti ohvitserid Põhja sõjas", Sõdur, 3 (1938), 69-71.

21 Dokument on publitseeritud Kalle Kroon, Kolme lõvi ja greifi all, 321-324.

22 Vt Aivar Põldvee, "Zwischen Pflug und Fibel: Bauernschulmeister und Leibeigenschaft in Est- und Livland im 17. Jahrhundert am Beispiel von Ignatsi Jaak und Bengt Adamson", Das Leben auf dem Lande im Baltikum: Elf Beiträge zum 18. Baltischen Seminar 2006, hrsg. von Jyrgen Heide (Lüneburg: Verlag Carl-Schirren-Gesellschaft, 2012), 234.

23 Loit, "Pärisorjuse kaotamine Eestis Rootsi ajal", 14.

24 Forseliuse seminari kohta lähemalt vt Aivar Põldvee, "Talurahvakoolid Eesti- ja Liivimaal 17. sajandi viimasel veerandil”, Eesti Ajalooarhiivi toimetised, 8 (2002), 82-155. 
Toomas (Joesoy Thomas). ${ }^{25}$ Seega oli tegu teisest kindralkubermangust pärit talupoegadega, mis näitab, et ametivaliku õigusega endised sunnismaised normatiivid enam ei kehtinud ning seda juba enne Karl XI 31. juuli 1687. aasta korraldust Eestimaale. Võimalik mõjutegur on eelpool mainitud 1681. aastal Liivi- ja Eestimaale moodustatud esimene ühine reduktsioonikomisjon. ${ }^{26}$ Osa seminari lõpetanud koolmeistritest asusid teenistusse Eestimaa kindralkubermangus Haljalas, Jõelähtmel, Lihulas ning Liivimaa kindralkubermangus Audrus ja Tõstamaal. ${ }^{27}$ Peale kindla õpetajakoha saanute leidus Forseliuse seminaris koolitust saanuid, kes käisid rändõpetajatena igal talvel ühes või teises kohas õpetamas, ${ }^{28}$ seega võisid oma ametiga seoses liikuda ja vabalt töötada. Aleksander Loidi andmeil on peale köster-koolmeistrite kaalutud veel teisi tsiviilametite võimalusi, nagu manufaktuuritöölise kutse. ${ }^{29}$

SunNiSMaISUS või INTEGRATSIOON? Tuginedes riigimõisate ökonoomiaasehalduri määrustele leiab Marten Seppel, et sisuliselt sarnanes riigitalupoegade olukord endiselt sunnismaisusele, mis kandus üle ka talupoegade poegadele. ${ }^{30} \mathrm{Ilmneb}$ näiline vastuolu ühelt poolt talupoegade poegadele ametivalikut võimaldanud kuninga 31. juuli 1687. aasta korralduse ja talupoegade liikumisvabaduse puudumise vahel. Kuninga, Liivimaa rüütelkonna ja Liivimaa reduktsioonikomisjoni vahelisest kirjavahetusest selgub, et oluliseks mõjuteguriks talupoegade paigalejätmiseks riigimõisatesse oli kuninga mure riigimõisatest laekuvate sissetulekute pärast ning esmapilgul näib, et siin on rüütelkond suutnud kuningat veenda. ${ }^{31}$ Tegelikult oli riigitalupoegade sunnismaisusele sarnanev seisund tingimuslik, kuivõrd nad olid rendile antud vaid teatud tingimustel ${ }^{32}$ ning nende pojad võisid vabalt asuda etteantud valikul ametitesse väljaspool traditsioonilist talupojaseisust. Ei saa päriselt nõustuda Seppeli väitega, nagu olnuks riigimõisate alla kuulumine talupoegade kui rentnike omandiline, seega ka pärisorjusele tunnuslik nähtus ning nagu olnuks see kuninga poolt

25 Põldvee, "Zwischen Pflug und Fibel”, 241; vt ka Aivar Põldvee teese käesolevas väitluses.

26 Loit, "Pärisorjuse kaotamine Eestis Rootsi ajal", 7.

27 Põldvee, "Zwischen Pflug und Fibel”, 255.

28 Ibid.

29 Loit, "Pärisorjuse kaotamine Eestis Rootsi ajal", 12.

30 Vt Marten Seppeli teese käesolevas väitluses.

31 Loit, "Pärisorjuse kaotamine Eestis Rootsi ajal", 8, 18.

32 Kroon, Kolme lóvi ja greifi all, 321-323. 
sellisena aktsepteeritud, ${ }^{33}$ sest riigimõisate talupojad ei olnud kuninga seisukohast rentnike pärisorjad, vaid kuninga alamad ning kuuluvus riigimõisa juurde ja konkreetsesse kindralkubermangu ei olnud ameti valinud talupoegade puhul päriluslikult enam määrav. ${ }^{34}$ Sellevõrra pidi ka majandusdokumentidesse edasikandunud mõiste "pärus" (Erb) ${ }^{35}$ olema muutunud tinglikuks, näidates ära nende päritolu, kuid mitte enam nende kategoorilist, st päriluslikku sunnismaisust. Tuleb vahet teha kuningliku korralduse ning lokaaltasandi määruste vahel. Rääkides kuninga 31. juuli 1687. aasta kirjast, tulenesid ökonoomiaasehaldurite määrused ja õigus riigitalupoegi mõisates kinni pidada ning neid vajadusel mõnda teise riigimõisa ümber paigutada, aga ka talupoegade poegadele antud reglementeeritud ametivaliku õigus sellestsamast kuninga korraldusest. Kuninga korraldust tuleb vaadelda ülimuslikuna, sest ei ökonoomiaasehalduri määrused ega 1696. aasta ökonoomiareglement ei saanud kuidagi käsitleda kuninga poolt antud riigitalupoegade sotsiaalseid õigusi, kuna need ei olnud ökonoomiaasehalduri kompetentsi kuuluvad. Küll aga on Liivimaa lokaalsel võimutasandil, 1698. aastal Laiusel üritatud köster-koolmeistreid "kui mõisnike pärisorjade lapsi" suruda tagasi mõisaorjusesse päruslikel tingimustel, st saata neid tagasi nende päritolukohtadesse, mida Laiuse pastor Reiner Broocmann on mõistnud kui siirdumist "jälle nende (mõisnike) orjadeks". ${ }^{36}$ See on üks näide feodaalse agraarühiskonna ja varakodanlikke reforme läbi viiva Rootsi kuningavõimu vahelisest võitlusest.

ORJUS vÕI VABADUS? Eraldi tuleb vaadelda küsimust, milline oli kuninga alamateks saanud talupoegade ja nende kaasaegsete nägemus "orjusest" ja "vabadusest". Orjusena on tajunud oma seisundit 1696. aastal Salatsi riigimõisa talupojad, kes soovisid üle minna kubermanguvalitsuse alluvuses raharendile, kuna vastasel korral ei pääsevat nad kunagi orjusest, "kuigi tema Kuningliku Majesteedi kõige armulisem soov on, et nõnda sünniks". ${ }^{37}$ Samuti on riigimõisate talupojad nii mõnigi kord allkirjastanud oma kaebekirjad kuninga “orjadena” ${ }^{38}$ Orjadena üritasid käsitleda endale määratud

33 Marten Seppel, ““'Aadel ei vöi türanniseerida talupoegi nii nagu tahab.” Mõisnike omavoli küsimus Liivi- ja Eestimaal”, Ajalooline Ajakiri, 1 (2010), 29.

34 Seda on näidanud ka Aivar Põldvee, " Zwischen Pflug und Fibel”, 266.

35 Vt Marten Seppel, "Kroonutalupoegade seisund Liivimaal 17. sajandi lõpus", Tuna, 2 (2005), 23-34.

36 Põldvee, "Zwischen Pflug und Fibel", 265.

37 Marten Seppel, "Liivi- ja Eestimaa talupoegade kaebereisid Stockholmi, 1681-170o", Läänemere provintside arenguperspektiivid Rootsi suurriigis 16/17. sajandil, III, koost Enn Küng, Eesti Ajalooarhiivi toimetised, 17 (Tartu, 2009), 364-365.

38 Kroon, Kolme lõvi ja greifi all, 325-326. 
talupoegi ka riigimõisate rentnikud, näiteks Eestimaal Risti kihelkonnas Kõmmaste mõisas ${ }^{39}$ ja Liivimaal Astijärve riigimõisas ${ }^{40}$.

Kuidas aga käsitleda lokaaltasandi kirjavahetuses riigimõisate talupoegade poolt kasutatud mõistet "orjus"? Kuninga ja keskvõimu seisukohast ei olnud riigimõisate talupojad enam mõisnike pärisorjad, vaid "kuulusid kuningale" ja olid "vabad mehed" ${ }^{41}$ Ent jätkuva mõisasunni tõttu mõistsid talupojad oma seisundit endiselt orjusena. Orjuse all mõisteti kohapeal eeskätt ikka ja alati allutatust mõisale, isegi kui tegu ei olnud mõisniku pärisorjaga. Talupoegade poegadele on ametivaliku realiseerimine seevastu kaasa toonud staatuse muutumise, mida kaasaegsed käsitlesid orjusest erinevana. Vabadusena pidid tajuma olukorda need talupojad, kes olid astunud nii enne kui ka pärast Põhjasõda vabatahtlikult armeesse. Ka Põhjasõja lõppedes oli talupoegadest sõdurite ja teatud osa aadli seisukohaks, et armees teeninud talupojad on vabad ja õigustatud endale vabalt elukohta valima. ${ }^{42}$ Laiuse pastor Broocmanni poolt kasutatud retoorika Laiuse köster-kooliõpetajate kaitsel tõendab, et köster-koolmeistri seisund oli erinev riigimõisas töötava talupoja omast, mida pastor pidas orjuseks - seega mõistetav vaba inimese seisundina. Kõige selgemini defineerituna ilmneb see praost Albrecht Sutori poolt esitatud Karl XI määrustes kösterkooliõpetaja Ignatsi Jaagu vabaduse kaitsel juba Vene võimu ajal. Põldvee näitab, et Tartu praostkonna praost Sutor tõi Ignatsi Jaagu ja tema laste pärisorjusest vabaks jäämise kaitseks (Denn so militiret fyr seine und der Kinder Freiheit von der Erbeigenschaft) esile järgmised punktid: 1) Tema Majesteedi Karl XI arm ja kavatsus; 2) (Kuninglikus) õiguses (Recht) välja antud eeskiri (Praescription); 3) isa Ignatsi Jaagu kauaaegne ustav teenistus ja 4) lastele antud hea haridus. ${ }^{43}$ Kui asetame neist kolm esimest punkti suhtesse kuningas Karl XI poolt välja antud korraldustega riigimõisate kohta, siis näeme, et Sutori väljendatud seisukohad kattuvad täielikult kuninga poolt antutega: 1) oma armus on Karl XI heaks arvanud ja väljendanud seisukohta talupoegade pärisorjus kaotada ja vabadus sisse juhatada; 2) oma kuninglikus õiguses on Karl XI välja andnud eeskirja, mille kohaselt kedagi talupoegade lastest ei tohi takistada nende tegelemisel raamatu-

39 Põldvee, "Zwischen Pflug und Fibel”, 260.

40 Seppel, "Aadel ei või türanniseerida talupoegi nii nagu tahab", 27.

41 EAA, f. 1, n. 2, s. 33, 1. 252; Laidre, Üks hä tru ja öige sullane, 361.

42 Eesti rahva ajaloost Põhjasõja aastail 170o-1721: valimik dokumente (Tallinn: Eesti Raamat, 1960), 317, 319. Tegelikult ei olnud siin tegu mitte "maamiilitsa", vaid riikliku nekrutikohuslusega, vt Kroon, Kolme lõvi ja greifi all, 75, 106-133, 139-183, 188-193, 332-338, 343-353, 357-370, 372-377.

43 Põldvee, "Zwischen Pflug und Fibel", 249. 
like kunstidega, siit ka ametivalikul ning 3) ametisse asunud talupoegade pojad on õigustatud oma ametit takistusteta pidama, kuni nad oma ametis ustavalt ja usinasti tegutsevad. ${ }^{44}$ Ühtlasi ilmneb, et jätkuvaks garantiiks pärisorjusest vaba olekuks on peale vaba isa ka lastele antud haridus. Sutori esitatud punktid manifesteerivad kuningas Karl XI poolt alustatud pärisorjuse kaotamise iseloomu kõige selgemal kujul.

KoKкUvõtтекs. Riigitalupojad ei olnud mõisnike pärisorjad, vaid kuulusid kuningale ning olid kuninga ja riigi alamad, mis tähendas talupoegade poegadele ametivaliku vabadust kuninga poolt etteantud raames. Nad võisid armeesse või tsiviilteenistusse asudes oma kodukohast ja riigimõisast lahkuda, mis tähendas ühtlasi mõisaliku kuuluvussuhte lakkamist tingimusel, et talupoeg end oma ametis õigustab. Käesolevas uurimisseisus vajab viimatimainitud tingimus veel edasist selgitustööd, kuid võib öelda, et kuuluvus (Hörigkeit) kuninga dispositsiooni alla, mõisnikest rääkimata, ei ole siin lõpuni defineeritav absoluutse sõltuvusvormina. Ühtlasi tähendas see eesti ja läti talupoegade sotsiaalse emantsipeerumise algust ühiskonda ja avalikku ellu viisil, et talupoeg oleks ühiskondlikult kasulik. Ametivaliku kitsapiirilisuse ja tingimuslikkusega sooviti vältida vabalt ringi hulkuvate ja kasutute talupoegade massi. Saksa ajalooteoreetiku Peter Blickle kriteeriumi järgi on pärisorjuse puudumise tunnuseks õigus käsutada vabalt omaenda tööjõudu. ${ }^{45}$ Märke talupoegade vaba tööjõu liikumisest näeme ka Eesti- ja Liivimaal Rootsi aja lõpul.

Kalle Kroon

\section{MÕNEST VABADUSE PROOVIKIVIST (RANNAROOTSLASTE JA KOOLMEISTRITE NÄITEL)}

Kuigi pärisorjuse kaotamise taotlusi 17. sajandil ei saa üks-üheselt võrrelda talurahva vabastamisega 19. sajandil, oli mõlemal juhul tegemist pikaajalise protsessiga, mille tulemused ei ilmutanud end üleöö, samuti ei puudunud

44 Kroon, Kolme lõvi ja greifi all, 318-319, 322-323.

45 Nii pärisorjuse lakkamise kriteeriumi kui ülemineku kohta pärisorjusest kodanikuühiskonnani vt Peter Blickle, Von der Leibeigenschaft zu den Menschenrechten: eine Geschichte der Freiheit in Deutschland (München: Beck, 2003). 
kummalgi juhul huvigrupid, kes töötasid uuendustele vastu, nagu ka need, kes hellitasid põhjendamatuid ootusi või ei saanud asja olemusest üldse aru. Karl XI talurahvapoliitika Eesti- ja Liivimaal on mitmeti tõlgendatav teema, mille puhul lisab "olekseid" asjaolu, et reformidele tõmbas paljuski kriipsu peale Põhjasõja-järgne restitutsioon. Siinse lühiülevaate eesmärgiks on vaadelda juhtumeid, kus talupojad (rannarootslased ja koolmeistrid) sattusid olukordadesse, mida saab käsitleda pärisorjuse kaotamise kontekstis. Laiema pildi loomine ja hindamine jäägu teistele.

Rannarootslased. Eestirootsi (Suur- ja Väike-Pakri, Laoküla, Vormsi, Noarootsi, Hiiumaa jt) talupoegade olukorda 17. sajandil on suhteliselt põhjalikult uuritud. ${ }^{46}$ Rannarootslaste õiguslik staatus erines valdava osa eesti talupoegade omast, kuna nad olid isiklikult vabad. Mitmel pool kinnitasid nende privilegeeritud seisundit ja kindlaid maksunorme keskaegsed vabadus- ja maaostukirjad (näiteks Laokülas ja Suur-Pakril), mille kinnitamist nõuti ka Rootsi võimudelt. Tegemist oli sotsiaalse grupiga, kelle õiguslik staatus vastas enam-vähem seisundile, mida võinuks taotleda pärisorjuse kaotamine Liivi- ja Eestimaal. Seoses laialdase maade läänistamisega tugevnes 17. sajandil pärisorjuslik surve, mis väljendus kõrgemates maksudes, teotöö nõudmises (ja tööpäevade arvu suurendamises), talumaade mõisastamises, talupoegade ümberpaigutamises, pärandvara omastamises jms. Vastuhakkude mahasurumiseks kasutati vägivalda ning püüti läbi viia "eestistamist" - ja seda mitte üksnes õiguslikus mõttes (nn rootsi õigus versus eesti õigus), vaid ka etniliselt, kuna rootsi päritolu ja keel olid üheks vabaduse väliseks tunnuseks. See etniliselt määratletud eristaatus kehtis reeglina küll vaid rannarootslaste kompaktse asustuse piirkondades. Kirjeldatud feodaalne surve on tinginud sümptomaatilise erinevuse eestlaste ja rannarootslaste ajaloomälus: viimaste jaoks pole 17. sajand "vana hea Rootsi aeg".

Karl XI reformid, eeskätt mõisate reduktsioon ei jätnud puudutamata ka rannarootslasi, kelle aktiivsus oma õiguste kaitsel 1680. aastatel järsult

46 Evald Blumfeldt, "Estlandssvenskarnas historia", En bok om Estlands svenskar, 1 (Stockholm: Kulturföreningen Svenska Odlingens Vänner, 1961), 65-178; Arnold Soom, "De estländssvenska Ormsö- och Nucköböndernas kamp mot det feodala oket under 160o-talet", Svio-Estonica, XIII (Ny följd 4) (Lund, 1956), 3-42; Arnold Soom, "Laoküla rootsi päritoluga vabatalupoegade vabaduse kaotus 17. sajandil”, Sõna, 6 (1949), 412-424; Jakob Koit, "De svenska dagöböndernas kamp för sina fri- och rättigheter 1662-1685", Svio-Estonica, X; Ny följd 1 (Lund, 1951), 50-153; Aivar Põldvee, Pakri rootslaste kaebused Karl XI-le 1684. aastal: muutuste aeg Harju-Madise ja Risti kihelkonnas, Harjumaa uurimusi, 4 (Keila: Harjumaa muuseum, 2001). 
tõusis. Üheks katalüsaatoriks sai keskvõimu taotlus (1681) panna eestirootsi talupojad, kes kasutavad "Rootsi vabadust, maneeri ja tingimusi", kandma sõjaväekohustust nagu talupojad Rootsis. Esialgu kavandati rannarootsi sõdurid koondada ooberst Knorringi jalaväerügementi, aga 1683. aastal otsustati rannarootslaste aladel sisse seada mereväeteenistuskohustus. Laevastikku pidi teenima minema iga viies meest eluaastates 15 kuni 50. Kuninga kirjas Eestimaa kuberner Robert Lichtonile anti teada, et "mainitud saarte" talupoegadele antakse lootust, et neid ei peeta sestpeale pärisorjadeks (lijfegne), vaid sündinud rootslasteks. 1684. aasta juulis oli kirja pandud 284 meest ja Hiiumaalt loodeti saada veel vähemalt 50. Admiraliteedikolleegiumi presidendile teatati, et mehed on "viimane kui üks ustav patrioot (trogen patriot)", kuid ometi on nad kohati olnud uskumatult jäärapäised, nõudes kõigepealt oma vanade privileegide kinnitamist. Õhus oli mässu eelaimdust, nii et kaaluti sõjaväelist karistusoperatsiooni. Samas oli juba teada, et vastuhaku ninamehed on sõitnud saadikutena Stockholmi.

Stockholmis esitatud kaebekirjade sisu oli siiski seotud feodaalse vägivalla juhtumitega, mereväeteenistuse küsimust pudutati vaid riivamisi. 18. augustil 1684 käskis Karl XI Eestimaa asehalduril Johann Christoph Scheidingil moodustada eestirootsi talupoegade kaebuste uurimiseks komisjon, mis pidi mh välja selgitama, miks on "iidsest ajast ja üle 300 aasta vabu talupoegi tahetud teha pärisorjadeks (lijfegne)". Komisjon tegutses Toompeal 1684. aasta detsembrist 1685. aasta aprillini, Rootsi riiginõukogu kuninga eesistumisel arutas eestirootslaste küsimust Stockholmis 30. septembril $1685 .{ }^{47}$ Riiginõukogu ette kutsutud talupoegade saadikutelt küsiti, mille põhjal nad nõuavad endale suuremat vabadust kui teised aadlitalupojad, st eestlased. Vastus kõlas, et oma endiste privileegide põhjal. Kuninga pärimise peale, kas nad on kroonu- või maksutalupojad, kosteti, et varem olid nad kroonutalupojad (kronobönder), nüüd aga maksutalupojad. Kohe parandati, et talupojad on eksinud mõistega, mispeale küsitletavad selgitasid, et nad olid küll kroonutalupojad, kuid seejärel müüdi aadlikule. ${ }^{48}$ Kuningas märkis, et esitatud dokumentide järgi on talupojad aadlitalupojad, samas aga paistab, et "ehkki nad on rootslased, pole neid

47 Istungi protokoll on publitseeritud: "Handlingar angående Svenska kolonier i Estland", Handlingar rörande Skandinaviens historia, 32 (Stockholm: Hörbergska boktryckeriet, 1851), 1-51 (33-49).

48 Rootsis kujunes läänisüsteem maksuvabaduse (frälse) andmise kaudu: kuningale osutatud teenete eest arvati rälsi- ehk aadlimaa riigi maksualuste maade hulgast välja. Sõltuvalt sellest, kas talupoeg elas Rootsis “oma”, kuninga või aadli maadel, võib neid laias laastus jagada kas maksu- (skatte-), kroonu- (krono-) või aadlitalupoegadeks (frälsebönder). 
teisiti koheldud kui muid talupoegi". Krahv Johan Stenbock viitas eelmiste Rootsi kuningate poolt eestirootslastele antud eesõigustele ning osutas vastuolule, et "kohati peetakse neid rootslasteks, kohati aga liivimaalasteks" (s.o pärisorjadeks). Seepeale meenutas kuningas, kuidas eestirootsi talupoegi taheti allutada mereväeteenistuse kohustusele, aga talupojad ise pidasid sel juhul paremaks olla "eesti õiguse" (Estnisk Rätt, s.o pärisorjus) all. Stenbocki arvates oleks aga liiga ränk, kui neid peetaks ühtaegu nii rootsi kui ka eesti talupoegadeks. Pika arutelu järel jõuti otsusele, et "need talupojad on vaba rahvas nagu aadlitalupojad siin Rootsis". Kui mõisahärrad neid liigselt koormavad, on neil õigus öelda oma koht üles ja pärast võlgade tasumist asuda elama mujale. Sarnane oli ka resolutsioon Hiiumaa rootsi talupoegade kohta 7. oktoobrist 1685 .

Arnold Soom hindab riiginõukogu otsust eestirootslaste võiduks neid ohustanud üha süvenevate feodaalsete tendentside üle, kuid möönab ka selle deklaratiivset iseloomu. Riiginõukogu istungi protokoll annab aimu, milline oli Rootsi võimuladviku ja kuninga arusaam Eesti- ja Liivimaa talupoegade õiguslikust staatusest. Aleksander Loidi hinnangul oli 1685. aasta sügisel talupoegade pärisorjusest vabastamine Eestimaa riigimõisates põhimõtteliselt otsustatud. ${ }^{49}$ Arutelu riiginõukogus, kus isegi eestirootsi talupoegade vabaks tunnistamine ei sündinud ideelise segaduse ja vaidlusteta, ei jäta muljet ühemõttelisest kursist pärisorjuse kaotamisele. Jätkus ka pärisorjuslik praktika ja aadli omavolitsemine rannarootsi talupoegade üle. Hiiumaa väikekülade talupoegade õiguste eest võidelnud Kidaste Jürgen veeti 1692. aastal karistuseks kuus korda läbi 300-mehelise kadalipu.

KoOLMEISTRID. Karl XI korralduses 31. juulist 1687, millega täpsustati kroonumõisate talupoegade õiguslikku seisundit, on klausel, et nendele talumeeste poegadele, kellel on huvi ja eeldusi raamatutarkuseks (bokliga konster) või kes tahavad sõjaväeteenistusse astuda, ei tohi takistusi teha.$^{50}$ Kõige kuulsamad koolipoisid sellest ajast on Ignatsi Jaak ja Pakri Hansu poeg Jüri, kes olid 1686. aasta lõpul Bengt Gottfried Forseliusega Stockholmis kaasas. Forselius meenutas Stockholmi-visiiti hiljem kirjas Eestimaa piiskopile nii: “Teie [...] võtsite mõlemad eesti poisid hästi vastu, kuulasite nende lugemist ja laulmist, kandsite tihtilugu suurt hoolt. Teie [...] käisite siin ja seal [palumas], kuni Teie minu ja mõlemad orjad [Sclaven] Tema Kuningliku Majesteedi ette viisite." Liivimaa kroonumõisates oli pärisorjus kaotatud juba 1681. aastal,

49 Loit, "Pärisorjuse kaotamine Eestis Rootsi ajal", 9.

50 Vt viide nr 21. 
aga Forselius pidas vajalikuks talupoisse ikkagi orjadeks nimetada. ${ }^{51}$ Kooliminekuks said kõigepealt õiguse kodust lahkuda need, peamiselt kahest Tartumaa praostkonnast pärit talupoisid, kes õppisid 1684.-86. aastal nn Forseliuse seminaris. Tublimad noormehed saadeti pärast kaks talve kestnud õpinguid koolmeistriteks, - ja sugugi mitte üksnes kodukihelkonda, vaid mõni koguni teise kubermangu, st Eestimaale. Kõige kaugemateks kohtadeks olid Haljala, Lihula, Audru ja Tõstamaa ning Jõelähtme ja Viimsi. Osa Forseliuse õpetatud poisse tegutses rändkoolmeistrina, asudes järgmisel talvel õpetama juba järgmises kohas, aga leidus ka selliseid, kes kutsuti tagasi ning jäidki kodukohast kaugel koolmeistri või köstrina paigale.

Üks silmapaistvamaid koolmeistreid oli Uustalu Bengt, kes tegutses lugemisõpetajana Forseliuse Tartu koolis. ${ }^{52}$ 1686. aastal sai temast koolmeister Sangastes ja 1688. aasta sügisel Harju-Madisel, kus ta õpetas nii eesti kui ka rootsi lapsi. Koolmeistrina kasutas ta rootsipärast nime Bengt Adamson. Tema isa oli Risti köster, rootsi päritolu Uustalu Adam. Kuna rootsi talupoegade privileegid kehtisid üksnes nende ajaloolistes asustuspiirkondades, nn vabadel maadel (fria länder), siis Risti kiriku lähedal sisemaal 3/4-adramaalises hajatalus elanud Uustalu Adama õiguslik seisund ei erinenud Kõmmaste küla eesti talupoegade omast. 1686. aastal sai temast kroonutalupoeg. 169o. aasta kevadel tekkis Kõmmaste rentnikul leitnant Caspar Johann von Dannenfeldil plaan köster Adam välja tõsta ning Uustalu maadele mõis rajada. Kuna Kõmmastes vaba maad ei olnud, sõlmis Dannenfeld 27. aprillil talupoja ümbertõstmise asjus lepingu Risti mõisniku Nicolai von Höwelniga, kellel oli vaba talukoht Kirikukülas. Lepingus ütleb Dannenfeld, et tegemist on hea talupojaga, keda ta ei taha ruineerida. Kuna Adam tahaks elupäevade lõpuni köstriametit pidada ning kirikhärrad Herlin ja Laurentius soovivad seda samuti, sest sellise palga eest pole võimalik uut köstrit leida, nõustuvad sellega ka Dannenfeld ja Höweln. Dokumendis loetakse üles talupoja pere ning kariloomad. Sealjuures lepiti kokku, et kui pärast Adama surma vajab Dannenfeld tema lapsi, peab Höweln nad loovutama koos kogu vara, kariloomade ja hobustega, kui aga sureb keegi Adama lastest (sh Bengt), kuulub nende isalt saadud pärand samuti Dannenfeldile. Lepingule kirjutasid kahe mõisniku kõrval tunnistajatena alla ka Harju-Madise pastor Gabriel Herlin ja diakon

\footnotetext{
${ }_{51}$ Vt Aivar Põldvee, "Kui Forselius Stockholmis käis", Haridus, 11-12 (2006), 17-22.

52 Aivar Põldvee, "Uustalu Bengti tundmatu elutee ja elutöö", Muinasaja loojangust omariikluse läveni. Pühendusteos Sulev Vahtre 75. sünnipäevaks, koost Andres Andresen (Tartu: Kleio, 2001), 205-221; Aivar Põldvee, "Lisandusi koolmeister Bengt Adamsoni eluloole", Haridus, 2 (2010), 4-45; Põldvee, “Zwischen Pflug und Fibel”, 231-269.
} 
Gustav Johann Laurentius. Herlin oli Forseliuse õemees ning kooliasjade ja koolmeistrite õigustega väga hästi kursis. Nagu näha, käsitati köstrist rootsi talupoega lepingus kui pärisorja ning see kehtis ka tema poja Bengti kohta. Kuninga 1687. aasta kirja kohaselt pidanuks talupoja ühest redutseeritud mõisast teise üleviimiseks loa andma kubermanguvalitsus, kuid seda dokument ei kajasta. Adama pojale Bengtile tagas liikumisvabaduse tema koolmeistristaatus.

1698. aastal protesteeris Laiuse kirikuõpetaja praost Reiner Broocmann mõisnike kavatsuse vastu eesti koolmeistrid kui oma pärisorjade lapsed tagasi nõuda ning palus Liivimaa konsistooriumilt selgitust, kuidas toimida, kui aadlikud peaks katsuma teha koolmeistreid "jälle oma orjadeks [Sklaven]”. 1699. aastal esitaski redutseeritud Laiuse mõis nõude, et kõik köstrid ja kooliõpetajad, kelle vanemad on olnud pärustalupojad (Erbbauern), tuleb ühes pere, vara ja kariloomadega välja anda ning tühjadesse taludesse paigutada. Laiuse mõisast oli pärit kuus sellist köstrit-koolmeistrit, kelle kaitseks Broocmann pöördus nüüd kindralkuberner Erik Dahlberghi poole. Viimane andis asehaldurile korralduse mõisarentnike omavolile lõpp teha. Kuna Kursi köster anti Laiusele välja, on Johan Kõpp oletanud, et sama saatus tabas ka teisi köster-koolmeistreid. ${ }^{53}$

КоккUvõTteKs. Rannarootslaste kaebuste käsitlemine Rootsi riiginõukogus osutab, et isegi Rootsi eliidil polnud täit selgust Eestimaa talupoegade õigusliku staatuse küsimuses, ja seda ajal, kui sarnased probleemid pidid juba olema kerkinud Liivimaa kroonumõisates ning olid kohe kerkimas seoses reduktsiooni läbiviimisega Eestimaal. Puudulik oli ka asjakohane kommunikatsioon, mis põhjustas vääritimõistmist ja sotsiaalset rahutust. Reduktsiooni järel jäi ka kroonumõisate rentnikele õigus (kubermanguvalitsuse loal) talupoegi ümber paigutada, kuid sõjaväkke või kooli minevatele talupoegadele ei tohtinud nad teha takistusi kodukohast lahkumiseks. Seda võib pidada sunnismaisuse kaotamiseks piiratud kujul. Samasuguse erandina saab käsitleda 1685 . aasta otsust rannarootsi talupoegade isikliku vabaduse kohta. Kõigele vaatamata kohtlesid mõisnikud sageli ka kroonutalupoegi kui oma pärustalupoegi ning ei tahtnud tunnistada ka koolmeistrina teenivate endiste pärisorjade isiklikku vabadust.

53 Johan Kõpp, Kirik ja rahvas. Sugemeid eesti rahva vaimse palge kujunemise teelt ([Stockholm]: Eesti Vaimulik Raamat, 1959 (Lund: Skånska Centraltryckeriet), 164-165. 
Järelloona tuleb meenutada ka Ignatsi Jaagu juhtumit. ${ }^{54}$ Rootsi ajal kroonutalupoegadeks muudetud talupoegadest said restitutsiooni käigus taas aadlile kuuluvad pärustalupojad. 1727. aastal hakkas Palupera mõisa uus omanik Franz von Rennenkampff Kambja köstrit ja koolmeistrit Ignatsi Jaaku ühes perekonnaga pärisorjaks tagasi nõudma, kuid kubermanguvalitsus lükkas taotluse tagasi. 1734. aastal esitas Rennenkampffi lesk Maria Sophia (snd von Liphart) sama nõude Tartu-Võru ülemkirikueestseisjale. Kambja pastor Albrecht Sutor astus oma köstri kaitseks välja ja selgitas, et pärisorjusest (Erbeigenschaft) vabastamise kindlustavad köstrile ja tema lastele kuningas Karl XI arm ja tahe, seadus, Ignatsi Jaagu kauaaegne truu teenistus ja tänuväärne õpetamistöö.

Küsimus, kuidas tajusid reduktsiooniga kaasnenud pärisorjuse kaotamist sotsiaalse muutusena kaasaegsed, vajaks põhjalikumat uurimist. Liivimaalt pärit Arvid Moller kirjutab oma kroonikas: "Aga kõige halvem oli, et ei siin [Tartus] ega kuskil kogu Eesti- ja Liivimaal ei leidunud kedagi, kes oskas raamatust lugeda, kuna nad olid raskes orjuses [träldom] ja härrased maal pidasid kasulikumaks hoida oma talupoegi harimatuses, et paremini nautida orjuse vilju. Seetõttu tahtsid nad panna kogu rahva uskuma, et Liivimaa talupoeg on loomu poolest nii rumal, et neid pole võimalik lugema õpetada, kuni üks Laiuse [sic!! pastoripoeg Bengt Forselius, kes oli õigusteaduse üliõpilane, võttis omal käel ette näidata vastupidist, ja sellele võis järgneda kuninglik korraldus talupojakoolide asutamiseks." ${ }^{55}$ Pärisorjuse kaotamist Moller miskipärast ei maini.

Aivar Põldvee

54 Ilje Piir, "Ignatsi Jaak ja tema järeltulijad", Wastne Testament 1686, konverentsi ettekanded 26.-27. aprill 1996, B. G. Forseliuse Seltsi Toimetised, 2 (Tartu, 1996), 65-70; Ilje Piir, Sulev Vahtre, "Ignatsi Jaak", Eesti ajalugu elulugudes: 101 tähtsat eestlast, koost Sulev Vahtre (Tallinn: Olion, 1997), 34-35; vt selle kohta ka Kalle Krooni teese käesolevas väitluses.

55 Arvid Moller, Fata Dorpati: den i förra tiden namnkunniga Lifländiska Staden Dorpts Öde (Wästerås, 1755), 54 . 


\section{Mis MUUTUS TALURAHVA SEISUNDIS?}

Aleksander Loit avaldas oma 1996. aastal ilmunud artiklis kindlat veendumust, et varasemas historiograafias domineerinud arvamus, nagu oleks kuningas Karl XI aadli vastuseisu tõttu juba 1681. aastal loobunud oma kavatsusest kaotada Liivimaal "vilets orjus ja pärisorjus", ei ole põhjendatud. ${ }^{56}$ Selle seisukohaga võib täielikult nõustuda. Kuningas mitte ainult ei jätkanud oma nõudmisi "pärisorjuse" kaotamise osas, vaid 1680.-90. aastatel viidi Liivi- ja Eestimaa kroonutalupojad selgelt erinevasse staatusesse võrreldes aadlitalupoegadega. Järgnevalt püüangi teha esmase kokkuvõtte, mis muutus ja mis ei muutunud kroonutalupoegade olukorras 17. sajandi lõpuks.

Tabel 1. Muutused kroonutalupoegade seisundis Eesti- ja Liivimaal 17. sajandi lõpus

\begin{tabular}{|l|c|c|c|}
\hline & Muutus & Ei muutunud & Lootus riigi kaitsele \\
\hline Talumaa valdamise õigus & & + & + \\
\hline $\begin{array}{l}\text { Vallasvara omandi- ja päri- } \\
\text { misõigus }\end{array}$ & & + & + \\
\hline $\begin{array}{l}\text { Mõisniku kohtuvõim ja } \\
\text { kodukariõigus }\end{array}$ & + & & + \\
\hline Kaebeõigus & + & & + \\
\hline $\begin{array}{l}\text { Omandiõiguslik kuulumine } \\
\text { ja talup. võõrandamine }\end{array}$ & + & & + \\
\hline Sunnismaisus & & + & + \\
\hline $\begin{array}{l}\text { Relva omamise ja kandmise } \\
\text { õigus }\end{array}$ & & + & + \\
\hline Andamid ja teotöö mõisale & & + & + \\
\hline Kauplemisõigus & & + & \\
\hline
\end{tabular}

Talupojad ei saavutanud enda käes oleva maa üle suuremat omandi- ega käsutamisõigust. Sarnaselt aadlitalupoegadele ei käsitatud kroonutalupoegi taluomanikena, vaid lihtsalt talu kasutajatena (aga mitte otseselt rentnikena). Talurahval oli keelatud talumaad tervenisti või osaliselt kellelegi kolmandale müüa või üürile anda. Seda on rõhutatud 1691. aasta Liivimaa ökonoomiaasehaldurite instruktsioonis. ${ }^{57}$ Väiksemate rakenduseta põllulappide

56 Loit, "Pärisorjuse kaotamine Eestis Rootsi ajal", 3-18.

57 "So muß auch kein Bauer oder Bewohner, bey harter Straffe, keinen Theil von des Gesindes Land und dazu gehörigen Gelegenheiten an einen Andern verhandeln, verheuren oder von Fremden bearbeiten und brauchen lassen" (Sammlung der Gesetze, welche das heutige livländische Landrecht enthalten, kritisch bearbeitet, hrsg. von G. Joh. v. Buddenbrock, 2-1 [B] (Riga, 1821), 1230-1231). 
teisele kasutada andmist esines aga tegelikkuses küll. 1694. aastal juunis andis selle vastu range korralduse Liivimaa ökonoomiaasehaldur Michael von Strokirch. Selle järgi tuli kroonutalurahvale tõsiselt selgitada, et "selline väljaüürimine on täielikult keelatud". Selliselt oma talumaad kellelegi teisele kasutada andnuid tuli esimesel ja teisel korral trahvida to paari vitstega iga väljaüüritud vakamaa kohta. Kui aga talupoeg tabatakse selliselt praktikalt kolmas kord, siis pidi ta jääma ilma nii oma maast kui ka kogu talukohast, kust ei tulnud teda mitte üksnes välja tõsta, vaid ta pidi ilma jääma ka seemnest ja tööst, mis ta oli juba sellel aastal teinud. Selle saagi pidi pooles osas saama pealekaebaja (Angeber) ja teine pool pidi minema kirikulaekasse. ${ }^{58}$

Samuti ei toimunud põhimõttelisi muutusi talupoegade omandi- ja pärimisõiguses vallasvara ja taluinventari üle. Selgelt aga saavutasid kroonutalupojad kindla kaitse oma vallasvara põhjendamata rekvireerimise vastu, kui selle üle kroonuadministratsioonile kaevati. Liivi- või Eestimaa kindralkubernerile või ökonoomiaasehalduritele laekunud talupoegade kaebuste puhul torkab 1690. aastatel sageli silma, et nendele reageerides nõutakse hoolimata asjaoludest talupojalt rekvireeritud vara kohest tagastamist. Nii näiteks ähvardas Eestimaa kindralkuberner Axel Julius De la Gardie 1697. aastal Uue-Kasti kroonumõisa rentnikku, et see peab kohe kõik talupoegadelt võetud vara nendele tagastama, kui ta ei soovi vastust anda fiskaalile. Kui rentnikul on midagi nendelt talupoegadelt sisse nõuda, siis peab ta oma pretensioonid kuningliku linnusekohtu ette tooma. ${ }^{59}$

Kõige suuremad muutused kroonutalupoegade olukorras seisnesid mõisa kodukari ja kohtuvõimu radikaalses piiramises. Mõisarentnikelt kohtuhärruse funktsiooni taandamine ei tähendanud mitte üksnes talupoegadele kaebeõiguse andmist, vaid ka olukorda, kus mõisarentnikud või mõisavalitsejad olid sunnitud mõnikord talupoegade karistamiseks pöörduma ise taotlusega asehalduri või kohtuinstantside poole. ${ }^{60} \mathrm{Näi-}$ teks nõudis Eestimaa kindralkuberner 1697. aastal Kunda talupoja Reino Hansu kaebuse peale, et kogu äravõetud vara (raha, hõbe ja vili) talupojale tagastataks ja kui mõisnikul peaks olema pretensioone, siis "peab ta tema [st talupoja] selle eest kohtu ette andma ja mitte, nagu juhtunud oli,

58 EAA, f. 278, n. 1, s. XVI-39f, 1. 4, Extract auß des Wohl geb. Königl. Hr. Stathalter von Strokirchen Ordre de datto Riga dn 14 Juny Anno 1694.

59 EAA, f. 1, n. 2, s. 135, 1. 101, Eestimaa kindralkuberneri resolutsioon Uue-Kasti talupoegade ja möldri kaebustele, 29.5.1697.

60 Vt nt Liivimaa kuberner Erik Soopi korraldust uurida maakohtul nii Piebalga talupoegade kaebust rentniku vastu kui sellesama rentniku vastukaebust nende talupoegade üle: EAA, f. 278, n. 1, s. IV-34:2, E. Soopi kiri Koknese maakohtule, 20.3.1696, konsept. 
ise kohtunik olema". ${ }^{61}$ Kroonutalupoegade kaebeõigus mitte üksnes ei laienenud, vaid see tagati kroonutalupoegadele ühemõtteliselt.

Talupoegade omandiõiguslikus kuuluvuses muutus muidugi kõige otsesemalt see, et eraomandist langeti kuninga omandisse. Talupojad vabastati personaalsest sõltuvusest mõisnikust/rentnikust ning sellega seoses võimaldati talupoegadele kaitset rentniku omavoli vastu. Samas näitab kroonutalupoegade jätkuvat omandiobjektiks olemise seisundit selgelt kroonuametkondadele jäänud õigus kroonutalurahvast ühest kohast teise ümber paigutada viisil, mis teeniks enim laekuvaid tulusid. ${ }^{62}$ Kroonutalupoegade transportimine ühest mõisast teise polnud küll väga laialdane praktika, kuid seda esines. Näiteks, kui 1694. aasta suve hakul oli vaja asustada Koknese kihelkonnas Lapinsky kroonumõisa neli tühja talu, andis ökonoomiaasehaldur Strokirch sellekohase korralduse koos täpsete juhistega, et sama kihelkonna Pasta mõisast viis metsatalupoega (Buschbauren) sinna kiiresti enne talivilja külvi algust ümber asustataks (transportiren).$^{63}$ Allikas pole mingit viidet, et see oleks toimunud kõnealuste talupoegade endi soovil.

Talupoegade sunnismaisuslik seisund ei muutunud. Talupojad kuulusid endiselt ühe kindla mõisa alla (mis küll ei pidanud olema enam isa- või sünnijärgne) ja mille rentnik võis alati pagenud talupoegi tagasi nõuda. Ökonoomiaasehaldur Strokirch on andnud arvukalt juhiseid ühe kroonumõisa alt teise kroonumõisa alla siirdunud talupoegade tagasitoomise kohta. ${ }^{64}$ Kui ökonoomiaasehaldurite korraldused pagenud kroonutalupoegade väljaandmisel jäid tulemusteta, siis on ka kindralkubernerid vastavaid korraldusi väljastanud. Näiteks oli Liivimaa kindralkuberner Erik Dahlbergh 1699. aastal sunnitud väljastama korralduse kahe Eestimaa Palu kroonumõisast pagenud talupoja (2 Königl. Erb-bauren) kättesaamiseks Liivimaalt "vastavalt maa konstitutsioonidele", kuna sellekohased

${ }_{61}$ EAA, f. 1, n. 2, s. 135, 1. 113p, Eestimaa kindralkuberneri resolutsioon Reino Hansu supliigile, 30.6.1697.

62 Elina Öpik pidas kroonutalupoegade üleviimise (transporteerimise) praktikat ühest kroonumõisast teise kõige selgemaks tõestuseks pärisorjuse kehtima jäämise kohta pärast reduktsiooni.

63 Latvijas Valsts vēstures arhīvs [edaspidi LVVA], 740o. f., 1. apr., 18. 1., 181. lp., Liivimaa ökonoomiaasehaldur M. v. Strokirch pr. Streiffile, 11.6.1694; vt ka EAA, f. 1, n. 2, s. 133, 1. 127p-128, Eestimaa kindralkuberner asehaldur Matthias von Portenile, 23.7.1695. ${ }^{64} \mathrm{Nt}$ 1699. aastal väljastatud volikirja järgi pidid Paltmale talupojad koos kogu varaga tagasi tooma Ikšķile mõisa alla pagenud Sigulda kroonutalupoja: LVVA, 740o. f., 1. apr., 22. 1., 120-120v. lpp., Pass für Paltmalsche Bauern, 22.3.1699. 
Eestimaa asehaldur Matthias von Porteni ega Liivimaa asehaldur Gustav Adolph von Strömfeldti korraldused polnud tulemust andnud. ${ }^{65}$

1996. aastal pakkus Aleksander Loit, et sunnismaisus kehtis ainult taluperemeeste kohta ning nooremad pojad pididki endile teise tegevusala otsima. ${ }^{66}$ Samal veendumusel on Kalle Kroon ${ }^{67}$ Selle kohta ei paku aga allikad mingit kinnitust. Kui näiteks Strati (Sturtzenhoff) kroonumõisa rentnik tahtis tagasi Sigulda kroonumõisa alla pagenud talupoega, kes oli oma isa juurest ära jooksnud, siis on Sigulda rentnik temalt palunud, et ta ootaks ainult nii kaua, kuni see sulane naise võtab, kuna ta olla juba kihlatud. Kui ta saatnud teisel korral sellele talupojale ja tema naisele oma inimesed järele, siis Sigulda rentnik keeldunud neid välja andmast. Selle peale väljastaski ökonoomiaasehaldur Strokirch korralduse Sigulda rentnikule, et viimasel pole mingit õigust sellele talupoisile (keine rechtmeßige ansprache auf selbigen Kerl hätte). ${ }^{68}$

Talupoegadele ei antud mingit vabadust relvadele, vaid jätkuvalt jäi kehtima põhimõte, et igas mõisas võib olla ainult kaks-kolm püssiga jahimeest. Liivimaa 1696. aasta ökonoomiareglemendi järgi ei tohtinud ühes mõisas olla üle kahe jahimehe. ${ }^{69}$ Põhjasõja ajal talupoegade maamiilitsarügemendi loomises on püütud näha tõendit aset leidnud talupoegade emantsipatsioonist, mis võimaldanudki "nende probleemitu ja massilise väkkekutsumise".70 Seega on püütud Põhjasõja-aegse talurahva värbamisega tõendada pärisorjuse kaotamise fakti, kuna rõhutatakse eeldust, et pärisori ei saa teenida armees. Selline eeldus on jäänud aga täiesti verifitseerimata. Ei saa tähelepanuta jääda tõsiasi, et Põhjasõja ajal ei tehtud maamiilitsa puhul teenistusse võttes mingit vahet kroonu- ja aadlimõisate talupoegade vahel. ${ }^{71}$ Samamoodi hakati Venemaal 1705. aastast regulaarselt nekruteid

65 LVVA, 7349. f., 1. apr., 51. 1., 582. lp., Liivimaa kindralkuberner E. Dahlbergh kapten Stackelbergile, 4.7.1699.

66 Leppik, "Seminar pärisorjuse kaotamisest Eestis Rootsi ajal”, 62.

67 Kroon, "Eestlaste vabadusest ja väest Rootsi aja lõpul", 41.

68 LVVA, 7400. f., 1. apr., 19. 1., 107. lp., Liivimaa ökonoomiaasehaldur M. v. Strokirch A. Koskullile, 18.4.1695; vt veel näiteid: Seppel, "Kroonutalupoegade seisund Liivimaal 17. sajandi lõpus", 25.

69 Sammlung der Gesetze, 1209.

70 Aleksander Loit, "Läänemere provintside riigiõiguslik asend Rootsi suurriigis 15611710 (1721)”, Läänemere provintside arenguperspektiivid Rootsi suurriigis 16/17. sajandil, koost Enn Küng, Eesti Ajalooarhiivi toimetised, 8 (15) (Tartu, 2002), 20-21; Aleksander Loit, "Die "alte gute Schwedenzeit" und ihre historische Bedeutung für das Baltikum", Die baltischen Staaten im Schnittpunkt der Entwicklugen: Vergangenheit und Gegenwart, hrsg. von Carsten Goehrke, Jürgen von Ungern-Sternberg (Basel: Schwabe Verlag, 2002), 81.

71 Kalle Kroon, "Eesti ja Läti jalavägi Rootsi armees", Akadeemia, 8 (1998), 1779; Kroon, "Eestlaste vabadusest", 42. 
võtma pärisorjade seast ning vajadusel moodustati maamiilitsarügemente ilma probleemita kuni 1861 . aastani. ${ }^{72}$ Sarnaselt pole mingit alust eeldada, et kooli astumine oleks eeldanud vaba talurahvast või kooliharidus oleks andnud automaatse vabanemise pärisorjuslikust seisusest (loomulikult võis see saada oluliseks tõukeks sotsiaalsele tõusule). Nii nekrutivõtt kui ka koolikohustus kehtestati kroonu- ja aadlitalupoegadele Eesti- ja Liivimaal 18. sajandil, ilma eelduseta talurahva vabadusest.

Talurahva kohustus teha mõisale teotööd ja tasuda mõisaandameid jäi oma olemuselt ja ulatuselt suuresti muutumatuks. Kroonutalupoegade mõisakohustused küll fikseeriti ja üha enam ka normeeriti (millest rohkem ei tohtinud rentnik trahvi ähvardusel nõuda).

Talurahva kauplemisõigused oluliselt ei muutunud. Talupoegade jätkuvat mittevaba ja mõisnike (rentnike) heaksarvamisest sõltuvat kauplemisõigust tõendab ilmekalt kindralkuberner Axel Julius De la Gardie 30. septembri 1696. aasta publikaat-korraldus kroonutalupoegade kariloomade ostmise-müümise kohta. Sellega avaldas kindralkuberner nördimust, et kuninglikud talupojad püüavad leivapuuduse hädas viia oma loomi ja rakendeid linna, et neid ruineerivalt madala hinna eest maha müüa. Selline tegevus aga laostavat kroonumõisate rentnikke, kes lähtusid inventariloendisse ülesmärgitud loomadest. Nõnda keelati kõigil trahvi ähvardusel edaspidi kroonutalupoegadelt loomade ostmine, kui just talupojal polnud ette näidata oma härralt saadud lubakirja ühe või teise looma müügiks. Kroonumõisate rentnikel soovitas aga kindralkuberner kõik talupoegade loomad märgistada, et keegi nendega ilma tähelepanu tõmbamata kaubelda ei saaks. ${ }^{73}$

Kokkuvõttes tuleb rõhutada, et Liivi- ja Eestimaa kubermanguvalitsuse ja ökonoomiaasehaldurite tegevus 1680.-90. aastatel oli selgelt kooskõlas kuninga nõudmiste ja juhtnööridega "pärisorjuse" kaotamise küsimuses. Pole mingit põhjust jääda talupoegade seisundi hindamisel tuginema ainult kuninga üksikutele kirjadele, vaid kohapealse administratsiooni laiaulatuslik allikamassiiv aitab keskvõimu seisukohti veel paremini avada. Kui 1690. aastate lõpus on talupojad kaevanud mõisa julmade karistuste või vara rekvireerimise üle, siis näiteks on Eestimaa kindralkuberner nii mõnigi

72 Samamoodi polnud Rooma impeeriumis orjade ja koloonide kasutamine sõjaväeteenistuses õiguslikult välistatud, vt: Stefan Knoch, Sklavenfürsorge im Römischen Reich: Formen und Motive (Hildesheim, Zürich, New York: Georg Olms, 2005), 153; C. R. Whittaker, "Circe's Pigs: from slavery to serfdom in the Later Roman world", Slavery and Abolition, 8 (1987), 110.

73 EAA, f. 1, n. 2, s. 34, 1. 222, Eestimaa kindralkuberner Axel Julius De la Gardie korraldus, 30.9.1696. 
kord oma vastustes rõhutanud sellise tegevuse otsest vastuolu kuningliku korraldusega $^{74}$

Väga selgelt nähtub Karl XI 31. juuli 1687. aasta kirjast, et mingil juhul ei taotlenud kuningas talupoegadele isikliku vabaduse andmist, vaid jutt käis kroonutalupoegade vabastamisest mõisnike eraomandist, omavoli alt ja talupoegade õigusest kaitsele. ${ }^{75} 1681$. aasta juulis selgitas Liivimaa rüütelkond oma vastuses Karl XI ettepanekule "orjus ja pärisorjus" kaotada, et ilma kodukarita ja pärushärrade omandiõiguseta talupoegade üle ei saa ükski aadlimees Liivimaal eksisteerida. ${ }^{76}$ Need oli põhjendatud kartused, kuna kodukari ja talupoegade alluvuse osas toimusidki kõige suuremad muutused pärast reduktsiooni Liivi- ja Eestimaal, lisaks kroonutalupoegadele osaks saanud riigiadministratsiooni poolt pakutavale kaitsele rentnike isepäise tegevuse vastu.

Marten Seppel

\section{AвstraCt: The status of peasantry in Estland and Livland at the end of the Swedish reign}

ENN KÜNG: In May 2013, a seminar on the topic "Serfdom or freedom: changes in the status of peasantry in the end of the Swedish reign" was held at the University of Tartu. It was instigated by a debate in the Estonian historical discourse during the last two decades on the status of the post-reduction crown peasantry in Estland and Livland. The debate started in 1996 when Aleksander Loit gave a paper titled "On the abolishment of serfdom in Estonia during the Swedish reign". There he presented a novel

\footnotetext{
${ }_{74}$ Nt EAA, f. 1, n. 2, s. 135, 1. 126p-127, Eestimaa kindralkuberner Johann Wilhelm Taubele, 11.8.1697.

75 Kiri on publitseeritud: Kroon, Kolme lõvi ja greifi all, lisa 3.

76 Die Recesse der livländischen Landtage aus den Jahren 1681 bis 1711: theils im Wortlaute, theils im Auszuge, hrsg. von Carl Schirren (Dorpat: E. J. Karow, 1865), 31. Sarnaselt kirjutas Robert Lichton 9. augustil 1681 kuningale: "om husdisciplinen och ägendomsrätten, hvaruti den rättmätige servituten allenast består", mis olid peamised aspektid talurahva vabaduse sisseviimisel kroonumõisates ("böndernas frihets introducerande vid E. Kungl. Maj:ts gods”), RA, Livonica II, vol. 134, Robert Lichton Karl XI-le, 9.8.1681.
} 
idea that King Charles XI of Sweden not only wanted to improve the situation of peasants in the Baltic provinces, but actually abolished serfdom in the manors nationalized during the reduction - in Livland in 1681 and in Estland in 1687. Several - but not all - historians agreed with Loit. In order to discuss this important issue more thoroughly a new debate was organized, the results of which are presented here.

AleKsander Loit: By the beginning of the seventeenth century, the former crown property in Estland and Livland was almost entirely enfeoffed to the nobility. The situation was reversed with the reduction when all the enfeoffments by Swedish authorities were renationalized and the majority of the arable land was taken back by the crown. Apart from the fact that the state revenues from Estland and Livland multiplied, the reduction brought along changes in the existing social order, such as the liquidation of the feudal system and the abolishment of serfdom. Peasants of the crown manors became the subjects of the king and had to be treated similarly to other peasants in the Swedish realm. Political power and the position of the nobility weakened both in relation to the monarchical power and the subordinated peasants. In crown manors, the feudal system was replaced by the lease holding system, whereby the leaseholders were not permitted to join the local knighthoods.

KALLE KROON: Nationalization of the crown manors in Estland and Livland at the end of the seventeenth century was accompanied by the abolishment of serfdom of the crown peasantry. Although the owners of farmsteads had to stay put, their sons were given the freedom to choose a profession, either by joining the army or by acquiring education for the position of a schoolmaster. The end to the attachment to land for the new generation and the freedom to decide over their own labor testify to the absence of serfdom, which is characteristic of the process of the abolishment of serfdom in Early Modern Europe at the end of the seventeenth and the beginning of the eighteenth century.

Aivar Póldvee: A more definite answer to the question of the abolishment of serfdom probably would be available if the Great Northern War had ended with Sweden's victory. Now one can only talk about the preliminary goals and the processes which were not accomplished. I focus on two issues, which can be taken as a model. First, the treatment of complaints by the peasants of Swedish origin who lived in Estonia by both the relevant 
commission and the council of the realm in 1684-85. The Swedish state viewed the legal status of the Swedish peasants in Estonia as some sort of an example to be applied to other peasants in Estland and Livland. However, the top officials in Sweden did not have a clear understanding what their status actually was. Only after a lengthy dispute, the council reached a conclusion in 1685 , according to which these peasants were as free as the nobility's peasants (frälsebönder) in Sweden. In reality, the resolution did not protect the Swedish peasants in Estonia from the encroachment of their rights by manor leaseholders. Secondly, there is a resolution from 1687 which demanded that the sons of peasants not be hindered in pursuing education (bokliga konster) or joining the army. In connection with the establishment of the peasant schools, both pupils and peasant schoolmasters achieved freedom of movement. There were schoolmasters who started to work far from their homes, even in another province. There were cases, however, when the leaseholders of crown estates demanded the return of schoolmasters as their former serfs. On the whole, the freedom of movement of schoolmasters testifies to the mitigation of serfdom.

MARTEN SePpel: What changed in the status of the peasantry in Estland and Livland at the end of the seventeenth century? The source material allows us to conclude that King Charles XI's demands to improve the status of the crown peasantry in Livland and Estland brought about three major changes in their condition: the judicial authority of the leaseholders of the crown estates was considerably restricted, the peasants' right to complain to the authorities was guaranteed, and the crown peasants were not to be sold. In other aspects, the status of the crown peasants changed little, although they could hope for protection from the provincial authorities against their leaseholders. The peasants' property and trading rights remained in principle the same as in the private estates; they had no right to leave their manor by their own will; they could not own guns or other weapons; their obligations of customary dues and statute labor was fixed and not substantially changed. The authorities' attitude toward the crown peasants can be characterized by the fact that similarly to serfs in private estates, they could be 'transported' from one crown manor to another whenever this was considered economically worthwhile. 
